Jacek W. CZARTOSZEWSKI*

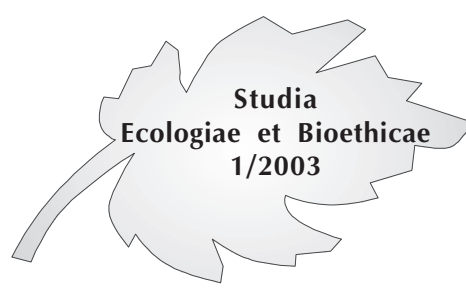

\title{
Zagadnienie światopoglądu w edukacji ekologicznej
}

Człowiek w znanym świecie (kosmosie) jest jedyną istotą, która wie, że istnieje. Ponadto zadaje sobie podstawowe pytania:

- Dlaczego istnieję?

- Co mogę wiedzieć?

- Co powinienem czynić?

- W czym mogę pokładać nadzieję?

- Czym/kim jestem?

Tego rodzaju pytania z zakresu metafizyki, religii, etyki i antropologii doszukują się sensu życia człowieka oraz skłaniają do wytworzenia światopoglądu, czyli zespołu poglądów stanowiących całościową wizję rzeczywistości, wyznaczających postępowanie człowieka względem siebie, innych ludzi i świata przyrody ${ }^{1}$.

Poszukiwanie własnego światopoglądu leży w naturze ludzkiej, gdyż inteligentny człowiek nie może żyć w próżni. Nie wystarczają mu fragmentaryczne doznania i fragmentaryczna wiedza. Dlatego próbuje w sposób aksjologiczny stworzyć we własnym umyśle uniwersalną koncepcję świata, w którym umieszcza sam siebie oraz środowisko społeczne i przyrodnicze, które go otacza.

Pojęcie światopoglądu na poziomie intuicji wydaje się jasne, lecz przy bliższym rozpatrywaniu bardzo często rodzą się wątpliwości.

\section{Czym jest światopogląd?}

W języku polskim termin "światopogląd" składa się z dwu członów „świat" i "pogląd"2. Jest poglądem człowieka na całość rzeczywistości, globalną interpretację świata ${ }^{3}$.

Instytut Ekologii i Bioetyki Uniwersytetu Kardynała Stefana Wyszyńskiego w Warszawie.

1 J. Herbut, Światopoglad, w: Leksykon filozofii klasycznej, red. J. Herbut, TN KUL Lublin 1997, s. 502-503.

2 Niemieckie: Weltanschauung i Weltbild; francuskie: le point de vue sur la vie; angielskie: world outlook.

3 S. Kowalczyк, Podstawy światopoglądu chrześcijańskiego, Wrocław 1995, s. 7; A. B. STE-PIEŃ, Uwagi o strukturze i typach światopoglądów, w: Oblicza dialogu. Z dziejów teorii dia- 


\section{1. Świat}

„Świat" (gr. kosmos; łac. mundus) jest pojęciem bardzo szerokim i wieloznacznym. Ogólnie w znaczeniu filozoficznym to ogół bytów stanowiących relacyjną całość.

Szczegółowsze określenia ujmują świat pojęty: obiektywnie, subiektywnie, ontologicznie i egzystencjalnie.

1. Świat pojęty obiektywnie to ogół wszystkich bytów skończonych stworzonych przez Absolut-Boga. Można również pojmować świat łącznie ze Stwórcą jako ogół bytów realnie istniejących.

2. Świat subiektywnie pojęty to ogół rzeczy, które są dane w potocznym doświadczeniu, dokonywanym $\mathrm{w}$ zaspokojeniu codziennych, praktycznych potrzeb ludzkich. Jest, zatem obrazem rzeczywistości dostępnym człowiekowi lub grupie (wspólnocie).

3. Świat pojęty ontologicznie to całość bytów cielesnych, jednolita, co do pewnych ich własności, badana przez filozoficzną kosmologię.

4. Świat pojmowany egzystencjalnie to $\mathrm{w}$ tradycji biblijnej civitas terrena, czyli ogół ludzi polegających na swych ludzkich siłach oraz przeciwstawny civitas Dei, czyli ogół ludzi poszukujących Boga.

Często świat określany jest na sposób:

1. Biologiczny jako świat życia otaczający poszczególne gatunki istot żywych, przestrzeń życiową lub środowisko, w którym żyje jednostka.

2. Kosmologiczny jako zbiorowisko ciał niebieskich opisywane teoretycznie przez przyrodniczą kosmologię.

3. Historyczny jako myślowe obrazy świata w określonych warunkach dziejowych.

W praktyce filozoficznej za desygnat terminu „świat” uważa się:

1. Całość przyrody.

2. Globalną problematykę społeczno-polityczną.

3. Globalne zagrożenia życia i zdrowia ludzi na ziemi.

4. Ujmowany całościowo postęp nauki, techniki i technologii,

5. Globalnie ujmowaną gospodarkę ludzką.

6. Rabunkową eksploatację planety Ziemia ${ }^{4}$. W praktyce naszej kultury z nazwą „świat” wiążą się inne desygnaty, np.:

1. Określony naród ze swoja kulturą, dziejami, tradycją, poglądami, wkładem do dziedzictwa światowego, ideami, wartościami, itp.

2. Określenie dziedziny życia, np. świat nauki, kultury, polityki, świat dziecka.

3. Rzeczywistość świecka odróżniana od religii i Kościoła.

logu: chrześcijanie-marksiści w Polsce, red. A. B. StęPIEń, T. Szubka, KUL Lublin 1992, s. 7-12.

4 J. Herbut, Świat, tamże, s. 501-502. 
4. Kwalifikacja moralna świata, zazwyczaj negatywna (tradycja platońska).

5. Życie duchowe lub religijne człowieka (świat duchowy).

6. Rzeczywistość nadprzyrodzoną, która z poziomu transcendencji pozostaje w rozlicznych związkach ze światem doczesnym ${ }^{5}$.

W ujęciach światopoglądowych komplementarna wizja świata rozumiana jest w kategoriach personalistycznych, to znaczy, że „świat osoby ludzkiej" zostaje uznany jako nadrzędny do świata materialnego, biologicznego i zwierzęcego, choć jest z nimi ściśle związany oraz uwarunkowany w swym istnieniu. Jawi się jako podmiot tworzący $w$ pewnym sensie siebie i dzieje wielu światów wchodzących w zakres rzeczywistości, np. świat kultury, nauki, polityki. Pomimo, że nie jest bytem pierwotnym, który ma moc decyzyjną w stosunku do rzeczywistości, lecz jest bytem względnym, wyrosłym na zastanej rzeczywistości, który nawet nie decyduje o swoim zaistnieniu, a rzeczywistość poznaje w sposób bardzo partykularny. Chodzi o uznanie, że świat zewnętrzny istnieje niezależnie od jednostki ludzkiej. Jest przez nią jedynie poznawany i nieznacznie modyfikowany.

\section{2. Pogląd}

„Pogląd”, czyli „wiedzieć ze zrozumieniem” wskazuje na podmiotowość oglądu świata. Spostrzeganie jest nie tylko zewnętrzną, pozapodmiotową czynnością oglądania rzeczy, zjawisk, ludzi, procesów, itp. Jest również czynnością oglądania wnętrza podmiotu, jego psychiki, życia duchowego. W skład poglądu na świat wchodzi i kształtuje go wiedza pochodząca z całościowego poznania człowieka, a więc z poznania potocznego, mądrościowego, naukowego, filozoficznego i religijnego ${ }^{6}$.

\section{2. 1. Poznanie i wiedza potoczna}

Wiedza potoczna, czyli zdroworozsądkowa (przednaukowa) jest najbardziej podstawowym i najpowszechniejszym typem wiedzy ludzkiej.

Obejmuje ona informacje, które wyrastają bezpośrednio z potrzeb życia codziennego oraz powstają spontanicznie, przypadkowo, pozaplanowo. Stąd wiadomości te $\mathrm{w}$ swej subiektywności są bardzo często nacechowane utylitaryzmem, niedokładnościami, czy nawet sprzecznościami. Stanowią one zlepek rozmaitych ujęć, zbitkę obrazów pochodzących z różnych punktów widzenia oraz często odmiennych poglądów. Zdrowy

5 M. Rusecki, Ku pojęciu światopoglądu, w: Z zagadnień światopoglądu chrześcijańskiego, red. M. RUSECKI, TN KUL Lublin 1989, s. 14.

6 Tamże, s. 16. 
rozsądek, który towarzyszy zdobywaniu wiedzy nie jest dostatecznym weryfikatorem-kontrolerem, stąd podmiot narażony jest na błędy i niespójności. Zdobywaniu tej wiedzy towarzyszy bardzo często pośpiech, brak głębszych przemyśleń, nieostrożność, brak racjonalności. Często też nadmierny wpływ $\mathrm{w}$ uznaniu wiedzy za prawdziwą ma wola podmiotu poznającego. Wreszcie wiedzy potocznej rzadko towarzyszy systematyczność i uporządkowanie, co prowadzi do licznych luk i braku powiązań, a w rezultacie do sprzeczności.

Zdobywanie tej wiedzy nie wymaga wykształcenia, ani specjalnych umiejętności. Stąd praktycznie każdy człowiek osiąga ją w miarę swych potrzeb i służy mu ona stale. Jest więc to wiedza podstawowa i powszechna. Ponadto nie wymaga ona falsyfikacji, co powoduje jej trwałość.

Pomimo fragmentaryczności, niedokładności, niesystematyczności, braku gruntownych uzasadnień, niespójności to jednak wiele stwierdzeń $\mathrm{w}$ niej zawartych jest prawdziwych, pewnych i nieomylnych ${ }^{7}$.

\section{2. 2. Wiedza mądrościowa}

Mądrość w znaczeniu najbardziej rozpowszechnionym to zdolność wrodzona lub nabyta, która wskazuje człowiekowi właściwy kierunek życia i pomaga mu zapewnić sobie pomyślność, a nawet szczęście. Nie pokrywa się ze szczegółową wiedzą, choć ją zakłada w tym stopniu, $\mathrm{w}$ którym jest ona potrzebna do właściwego postępowania w konkretnych okolicznościach. Źródłem mądrości jest zarówno doświadczenie osobiste, jak i zdroworozsądkowa obserwacja zachowania ludzi oraz prawidłowości przyrody. Przejawy mądrości są zależne od danej kultury, w szczególności od religii i filozofii ${ }^{8}$. Stąd wiedza potoczna poddana analizie, która ma za podstawę wieloaspektowe doświadczenie i przeżywanie osobowe rzeczywistości ze znajomością przyczyn bytu oraz uporządkowanie jej według aksjologicznej hierarchii staje się wiedzą mądrościową. Mądrość zapodmiotowana $\mathrm{w}$ człowieku pozwala mu na zachowanie dystansu wobec problemów spotykanych w życiu, które nie mają wielkiej wagi, widzi je bowiem $\mathrm{w}$ szerszej perspektywie wartości naczelnych, $\mathrm{z}$ którymi wiąże swoje życie. Na mądrość tego typu składają się osobiste doświadczenia, obserwacja i przemyślenia człowieka, a także doświadczenia innych ludzi i narodów przekazywane poprzez tradycję, wiedzę naukową i religijną .

7 S. Kamiński, Światopogląd - religia - teologia. Zagadnienia filozoficzne i metodologiczne, TN KUL Lublin 1998, s. 20.

8 J. Herbut, M. ŻARdecKa, Mądrość, w: Leksykon, s. 351-352.

9 M. RuSECKI, tamże, s.17-18. 


\section{2. 3. Poznanie naukowe}

Nauka charakteryzuje się skrupulatnością w determinacji swojego pola badań, co prowadzi do wąskiej specjalizacji, zaprowadza porządek w odniesieniu do języka oraz do twierdzeń, które przyjmuje. Ponadto za najważniejsze kryterium naukowości uważa się kontrolowalność spójności i uprawomocnienia tez oraz uznanie ich jako prowizoryczne, niepewne, hipotetyczne. Wreszcie nauka dba o obiektywność, uporządkowanie rzeczowe i logiczne ${ }^{10}$.

Poznanie naukowe napotyka szereg trudności, które nie pozwalają mu zachować metodologiczną czystość zawartą w założeniach. Podstawą tych trudności jest najczęściej człowiek, który czasami do procesu poznawczego wprowadza elementy wolitywne i emocjonalne.

$\mathrm{Z}$ osiągnięciami nauki winien liczyć się każdy, tym niemniej nauka bardzo często nie tylko nie rozwiązuje wszystkich problemów wchodzących w zakres światopoglądu, ale nawet ich nie podejmuje ${ }^{11}$.

\section{2. 4. Poznanie filozoficzne}

Filozofię w aspekcie światopoglądowym można pojmować jako myślenie ludzkie, które za cel stawia sobie rozwiązywanie ogólnych problemów dotyczących całej rzeczywistości, dokładniej mówiąc, która wyjaśnia w kategoriach ostatecznych istnienie bytu jako bytu, czyli całej rzeczywistości, co w sposób szczególny interesuje człowieka. Zadanie to wynika z natury samej filozofii, która chce być nauką o całej rzeczywistości, wyjaśniającą ją i tłumaczącą w świetle racji ostatecznych. Dążącą do znalezienia racji istnienia wszystkiego, co istnieje, czyli znalezienia przesłanek sensownie wyjaśniających istnienie bytu jako bytu ${ }^{12}$.

Dane dostarczane przez filozofię, rozumianą jako dziedzina wiedzy ludzkiej wyjaśniająca istnienie całej rzeczywistości w aspekcie racji ostatecznych, wnoszą wiele cennych elementów niezbędnych do formowania poglądu na świat.

\section{2. 5. Wiedza religijna}

Poznanie ludzkie nie może w pełni swym zasięgiem objąć całej rzeczywistości realnie istniejącej, gdyż należy do niej świat nadprzyrodzony. Istnienie bytu może jedynie wskazywać na niego, świadczyć o nim. Nie zajmuje się jednak nim wprost, ani też jego bezpośrednim stosun-

10 S. Kamiński, tamże, s. 21; J. Herbut, Wiedza, w: tamże, s. 537-530.

11 M. Rusecki, tamże, s. 20.

12 M. A. Krąpiec, Filozofia i Bóg, w: Studia z filozofii Boga, red. B. Bejze, t. 1, Warszawa 1968, s. 345. 
kiem do rzeczywistości. Stąd poznajemy świat nadprzyrodzony jedynie na poziomie objawienia. Przyjmując i interpretując to, co Bóg udostępnił człowiekowi.

Objawienie Boże jest poznawalne dla człowieka nie bezpośrednio, lecz w znakach i poprzez znaki epifanijne, które są adresowane do świadków objawienia. Ci zaś odczytując ich sens przekazują rozpoznane i zwiastowane im orędzie Boże wszystkim chcącym je rozpoznać w wierze. Znaki objawienia poddawane są krytycznej ocenie i podlegają uzasadnieniom.

Pełnię objawienia urzeczywistniła się w osobie Jezusa Chrystusa, który w sposób najpełniejszy i najdoskonalszy objawił ludzkości Boga. Chrześcijanin wierzy ze względu na Chrystusa, Jego życie, naukę, dzieła, mękę i śmierć dobrowolnie przyjętą oraz zmartwychwstanie.

Wszystkie religie są fenomenem powszechnym w sensie historycznym i geograficznym, wszystkie bazują na objawieniu Boga poprzez stworzenie i w stworzeniu. Objawienie daje człowiekowi nowe pole widzenia siebie i wszystkiego, co go otacza. Stąd wpływ religii na pogląd dotyczący świata i człowieka oraz na ich interpretację jest powszechny ${ }^{13}$.

\section{3. Problemy światopoglądowe}

Każdy człowiek w swoim życiu podejmuje procesy poznawcze, które są mu potrzebne do rozwiązywania problemów życiowych, bądź zaspokojenia zainteresowań, czy znalezienia sensu swego życia. Prowadzi to do osiągnięcia pewnego zasobu wiedzy, która całościowo wpływa na rozumienie (pojmowanie) otaczającej rzeczywistości ${ }^{14}$.

Oczywiście człowiek $\mathrm{w}$ miarę narastania pytań dotyczących świata i człowieka dodaje od siebie twierdzenia dotyczące obyczajów, moralności, estetyki, prawa, religii, eschatologii, teologii, filozofii i przyrody. Suma tych twierdzeń wpływa na osobisty, niepowtarzalny pogląd na świat, konkretnej osoby. Nie jest to oczywiście wszystko, co dany człowiek wie, lecz tylko ta część jego wiedzy, która wyraża jego osobiste przekonanie, co do tego, jak jest. Przy czym wiedza ta ma charakter mądrościowy. Zawiera bardziej lub mniej ostre odpowiedzi ${ }^{15}$.

Światopogląd jest żywy, ciągle zmienia się lub umacnia, bowiem każde nowe pytanie powoduje wprowadzenie odpowiedzi $\mathrm{w}$ postaci twierdzenia, które jest mechanicznie dodawane do posiadanej już sumy twierdzeń. Ta suma poszerza się i stanowi coraz dojrzalszy, pełniejszy (gdy twierdzenia są prawdziwe) obraz świata i człowieka ${ }^{16}$.

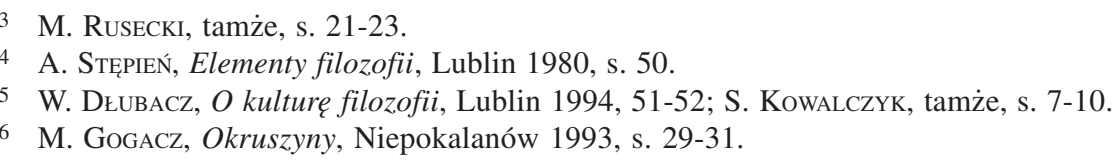


Ta prywatna wizja świata potrzebna człowiekowi jest do uzasadniania codziennych działań, w chwili, gdy nie wie jak postąpić, jak zachować się, by mógł w niej szukać podstawy rozstrzygnięć. Oczywiście, nie każde twierdzenie zakodowane $\mathrm{w}$ światopoglądzie ma taką samą wartość. Lecz zawsze światopogląd jest stanowiskiem, z którego wszystkie inne sprawy są oceniane, a człowiek nie może wykroczyć poza swoje założenia ${ }^{17}$.

Światopogląd spełnia potrzebę posiadania wiedzy, potrzebę pewności i wewnętrznego spokoju, że dana osoba postępuje słusznie. Pełni psychologicznie ważną rolę w życiu każdego człowieka ${ }^{18}$.

Światopoglądu nie można jako całości naukowo uzasadnić, gdyż nie ma takiej metody. Jest on niedowodliwy, ponieważ pod względem formy jest sprawą wiary a nie nauki ${ }^{19}$.

\section{Ekologia}

Współcześnie termin „ekologia” i „ekologiczny” jest bardzo różnie rozumiany:

1. "ekologia” to jedna z dziedzin biologii badająca wzajemne relacje między organizmami a środowiskiem życia tych organizmów. Jako dziedzina nauki nie zajmuje się bezpośrednio problemami ochrony przyrody i ochrony środowiska. ${ }^{20}$

2. "ekologia człowieka" to

3. "ekologiczny" to przyrodniczy, nieskażony, środowiskowy.

4. "ekologiczny" to produkt naturalny, zdrowy w odróżnieniu od "sztucznego", wytworzonego przez człowieka.

5. „ekologia” to dla wielu współczesnych ludzi teoria i praktyka ochrony środowiska.

6. „ekologia” to credo ideologii ruchów społecznych, „partii zielonych” (zwolenników „świętości natury”, wszelkiego życia, itp.). ${ }^{21}$

\section{Potrzeba światopoglądu ekologicznego}

Między twierdzeniami wpływającymi na dany pogląd na świat możemy wyróżnić dominujące. One wyznaczają charakter i odmianę światopo-

17 JAN PAWEe II, Fides et ratio, 29.

18 J. Herbut, Światopoglad, s. 502-503.

19 J. M. Bocheński, Sens życia i inne eseje, Kraków 1993, s. 163-171.

20 Kompendium wiedzy o ekologii, red. J. Strzalko i T. Mossor-PietraszewsKa, s. 360-361.

21 Z. Hull, Światopopgląd ekologiczny a ekologia i nauki o ochronie i ksztattowaniu środowiska, w: Światopogląd i ekologia, red. J. DЕ̨воwski, Olsztyn 1997, s. 56-57. 
glądu. Stąd możemy wyróżnić światopoglądy: aksjologiczne, estetyczne, prawnicze, religijne, eschatyczne, teologiczne, filozoficzne, przyrodnicze, itd..$^{22}$. Wśród nich powinniśmy również wyróżnić światopogląd oparty na myśleniu ekologicznym, przyjmujący określone wartości ekologiczne. Powinien on mieć treści dotyczące godności człowieka, który jest skazany na uzależnienie od obecnych trybów systemu technokratycznego, cierpiącego z powodu skażenia środowiska naturalnego, konsumpcjonizmu i nieograniczonej socjotechniki. Uświadamiać winien on też to, iż dewastacja środowiska naturalnego nie jest złem koniecznym, wynikającym z uprzemysłowienia świata, lecz rezultatem ułomnego, mechanistycznego myślenia ${ }^{23}$.

\subsection{Trudności}

Niestety wiedzę wpływającą na światopogląd człowiek czerpie nie tylko z poważnych publikacji, wykładów i prelekcji odpowiedzialnych nauczycieli, lecz przede wszystkim z domu rodzinnego, sąsiedztwa (podwórka), kontaktów z ludźmi w grupach: rówieśniczych, zawodowych, okazjonalnych (np. rozmowy w pociągu, w wojsku, itd.); z prasy, radia, telewizji, prywatnych lektur, szkoły, $\mathrm{z}$ nauczania religijnego. Niemały wpływ na światopogląd mają przeciwności życiowe, przeżycia artystyczne i estetyczne oraz problemy o podłożu ekonomicznym. Docenić powinniśmy też ogromną rolę zdrowia psychicznego oraz rozwój duchowy każdego człowieka. Zarówno pozytywną, jak i negatywną. Stąd pogląd mówiący o światopoglądzie opartym na filozofii ekologicznej (ekofilozofii) jest jedynie marzeniem ekologów i sozologów ${ }^{24}$.

W zasadzie występują $\mathrm{w}$ populacji takie światopoglądy, jakie są społeczności, jakie funkcjonują w nich rodziny, jacy żyją w nich ludzie, jakie wyznaczają sobie cele życiowe, jakie wartości stawiają sobie i społecznościom na pierwszych miejscach.

Obecnie w społeczeństwach końca dwudziestego wieku możemy zaobserwować nadmiar informacji docierających do człowieka. Informacje te bardzo często zaprzeczają sobie nawzajem, co powoduje utratę sprawności wiedzy, chaos (szum informatyczny), któremu człowiek nie jest w stanie zaradzić. Często prowadzi to osobę do ucieczki od realistycznego pojmowania świata. Człowiek nie znajdując możliwości rozumowego pojmowania otaczającej rzeczywistości (sprawności poznawczej intelektu) przechodzi na poziom wyobrażeń, uczuć, z którego wobec zaniku cnoty zwanej roztropnością nie jest $\mathrm{w}$ stanie sam oderwać się. Wpływa to na błędny (niepożądany) rozwój światopoglądu danej osoby.

\footnotetext{
22 Gogacz, tamże, s. 31-32.

23 S. KozŁowski, $W$ drodze do ekorozwoju, Warszawa 1997, s. 46.

24 Tamże, s. 46-48.
} 
Oczywiście na rozwój światopoglądów poszczególnych ludzi żyjących w naszym społeczeństwie możemy i powinniśmy wpływać. Poprzez edukację pojętą całościowo oraz zapewnienie bezpiecznego funkcjonowania $\mathrm{w}$ społeczeństwie. Poczynając od ochrony biologicznej i społecznej prawidłowego rozwoju płodu ludzkiego już w łonie matki. Dalej poprzez zapewnienie rozwoju w zdrowej, dobrej, kochającej się rodzinie. Później dobra szkoła skierowująca na realistyczne rozumienie otaczającego świata poprzez całościowe kształcenie w zakresie nauk humanistycznych, społecznych i przyrodniczych nie zapominając o wychowaniu do poszanowania otaczającego środowiska. Wreszcie ochrona człowieka przed socjotechniką nastawioną na konsumpcję, czy interesy jakiejś grupy (np. partii, korporacji, grupy zawodowej, itp.). Niemałą rolę $w$ kształtowaniu poprawnego światopoglądu ekologicznego ma zastane skażenie środowiska i problemy z niego wynikające. Pamiętać też trzeba o tym, iż brak problemów związanych ze skażeniem bez uwrażliwienia powoduje światopoglądowe pomijanie problemów. Stąd potrzeba dobrej edukacji ekologicznej.

\section{Kształtowanie świadomości ekologicznej}

Świadomość ekologiczna dotąd nie została jednoznacznie określona. Główną przyczyną tego stanu są trudności wyodrębnienia ze stanu ludzkiego myślenia sfer dotyczących ekologii. Ujmuje się ją w sposób opisowy i postulatywny.

Definicje opisowe podają, że świadomość ekologiczna to:

1. Warstwa świadomości społecznej, w której rozpoznawane są warunki i możliwości realizacji wartości ludzkich mających związki z otaczającym światem przyrody ${ }^{25}$;

2. Całokształt idei, poglądów i wyobrażeń oraz poznanych zasad kształtowania stosunków społeczeństwo-przyroda ${ }^{26}$;

3. Zespół informacji i przekonań na temat środowiska naturalnego oraz postrzegania związków między stanem i charakterem środowiska naturalnego a warunkami i jakością życia człowieka ${ }^{27}$;

4. Stosunek człowieka do środowiska przyrodniczego, zespół informacji i przekonań na jego temat, a także system wartości, jakim ta osoba kieruje się wobec niego w swoim postępowaniu ${ }^{28}$.

25 K. Łastowski, M. Rafiński, Stowo wstępne, w: Idee ekologii w świadomości społecznej, Poznań 1992, s. 4.

26 B. Poskrobкo, Wybrane aspekty świadomości ekologicznej mieszkańców Białostocczyzny, „Region Białostocki. Studia Ekonomiczno-Społeczne”, t. 9, Białystok 1990, s. 47.

27 T. Burger, Uwagi o świadomości ekologicznej, „Przegląd Powszechny” 12 (1986), s. 374.

28 D. KieŁCZEWski, Ekologia społeczna, Białystok 1999, s. 20. 
Jedna z definicji postulatywnych określa świadomość ekologiczną jako głębokie, doprowadzone do automatyzmu zrozumienie nierozerwalnej więzi człowieka i ludzkości z przyrodą oraz zależność dobrobytu od całościowej i względnej niezmienności naturalnego środowiska człowieka ${ }^{29}$.

Jak widać z powyższych definicji świadomość ekologiczna jest tylko zespołem elementów wchodzących w skład światopoglądu człowieka. Ważny jest tu czynnik aksjologiczny, który kształtuje postawę człowieka.

\section{Zakończenie}

Wiek XXI niesie wyzwanie dla ludzkości w postaci uświadomienia braków (nieprawidłowości) w stanie środowisk społecznych jak również ogromne skażenie środowiska przyrodniczego. Problem ten może rozwiązać jedynie uświadomienie miejsca człowieka w świecie względem Absolutu i innych bytów przygodnych, oraz powszechna zmiana świadomości ludzi polegająca na wzmocnieniu miłości do innych ludzi, która naprawi zło umiejscowione między ludźmi, połączona ze zmianą mentalności polegającej na samoograniczeniu korzystania z dóbr materialnych (oszczędności w zużywaniu z energii i surowców) oraz zadbania o pozostawienie dla przyszłych pokoleń środowiska przyrodniczego $\mathrm{w}$ stanie lepszym niż obecnie. Wymaga to stworzenia na wysokim poziomie poczucia świadomości ekologicznej. Niesie to przed sobą konieczność wypracowania $\mathrm{w}$ społeczeństwach nowego światopoglądu ukierunkowanego na myślenie ekologiczne, przyjmującego wartości ekologiczne.

Światopogląd ten unikając idealizmów i nieścisłości powinien być oparty na realnych podstawach $\mathrm{w}$ orientacji arystotelesowsko-tomistycznej. Ponadto musi unikać luk w wiedzy, stąd społeczności oprócz wiedzy przyrodniczej, technicznej, prawniczej i ekonomicznej powinny posiadać wiedzę humanistyczną dotyczącą zwłaszcza antropologii, aksjologii, teodycei i religii, zdobywanej w sposób kompleksowy przy pomocy poznania zdroworozsądkowego, mądrościowego, naukowego, filozoficznego i religijnego. $W$ przeciwnym razie luki, nieścisłości, a nawet sprzeczności w rozumieniu świata zdominują i doprowadzą do kłótni i antagonizmów.

Stąd płynie ogromne wyzwanie dla elit, które powinny wziąć na swe ramiona odpowiedzialność za przyszłość naszej planety i ludzkości.

29 G. Dobrzański, B. M. DobrZAŃsKa, D. KietCZewsKi, Ochrona środowiska przyrodniczego, Białystok 1997, s. 298-299. 


\title{
The structure of ecological outlook
}

\begin{abstract}
SUMMARY
The XXI century for humanity is a challange in awarness of failures in condition of social environment as well in huge contamination of nature. This problem can be resolved only on the way of grasping junctures man in the world toward Absolute and the others adventitious entities. There is necessary general change of human awarness, which will strengthen love to the other people and amends an evil site between mankind. It should be joined with changing mentality reducing consumption material goods (savings in using up energies and industrial goods) and taking care of remaining for succeeding generations natural environments on better condition than that nowadays. It also needs to create new high level of outlook upon ecology, which accept ecological values.

This outlook eschewing idealism and inaccuracies should be based on the real ground of aristotelic and thomistic orientation. Moreover it must avoid hatchway in the knowledge, from here society aside from knowledge natures, technical, juridical and economical should own knowing humanistic, which regards antropology, axioms, theology and religion (get into completely mode with helping of recognition common sense, wisdom, scientific, philosophic and religionist). On the other way hatchways, inaccuracies, and even contrarieties into understanding the world will become dominant and lead to quarrels and antagonisms.

From here floats huge challenge for leaders, who should take on their own shoulder responsibility upon future of our planet and humanity.
\end{abstract}

